\title{
BIOCHEMICAL AND CLINICAL STUDIES ON 4 CASES OF HEPATIC GLYCOGEN STORAGE DISEASE( Abstract_要旨 )
}

AUTHOR(S):

Sano, Masaju

CITATION:

Sano, Masaju. BIOCHEMICAL AND CLINICAL STUDIES ON 4 CASES OF HEPATIC GLYCOGEN STORAGE DISEASE. 京都大学, 1974, 医学博士

\section{ISSUE DATE:}

1974-03-23

URL:

http://hdl.handle.net/2433/220263

RIGHT: 


\section{【116】}

氏 名 佐野 萬 瑳 壽

学位の種 類 医 学 博士 学位記 番号 医 博 第 458 号 学位授与の日付 昭和 49 年 3 月 23 日 学位授与の要件 学位規則第 5 条第 1 項該当

研究科・専攻 医学研究科内科系専攻

学位論文題目

\section{BIOCHEMICAL AND CLINICAL STUDIES ON 4 CASES OF HEPATIC GLYCOGEN STORAGE DISEASE}

(肝糖原病の 4 例に関する生化学的及び臨床的研究)

主 查)

論文調査委員教授 本庄一夫教授沼正作 教授深瀬政市

\section{論文内容の要旨}

糖原病は先天的な酵素欠損にもとづく疾患であり, 現在では 6 種以上の病型が存在し, 中には複数の酵 素欠損を有する例があることが判明している。そして少くとも 4 種の病型では肝に病変が存在することが 明らかにされている。また本病の臨床像, 病理組織学的所見は各病型につき特徴的な所見に乏しく, 病型 の確実なる診断は肝及びその他藏器の酵素活性の測定に依らねばならない。しかし臨床的に各種の負荷試 験を実施することにより糖原病の病型の診断がある程度可能とされる。

本論文に招いては肝糖原病の 4 症例を検索対象とし，種々の臨床生化学的検査を実施すると共に，生検 肝組織及び筋組織を用い糖代謝に関する諸酵素活性を測定し糖原病の病型㡎断及び病態に関して検討を加 えた。

実施した臨床検査の中, 主なるものはブドウ糖負荷試験, ガラクトース負荷試験（ガラクトース負荷に より血糖值の上昇を観察)，エピネフリン試験（エピネフリン投与による血糖上昇観察），グルカゴン二重 負荷試験（空腹時及び食後 2 時間にグルカゴンを投与し血糖值の上昇を推察）である。開腹手術で得られ た肝及び同時に得られた筋肉につきグリコーゲン含有量の測定, グリコーゲンの構造決定を実施すると共 に, 3 症例については Glucase 6 phosphatase, phosphorylase, Amylo 1, 6 glucosidase, $\alpha$ Glucosidase 活性を測定したが，残り 1 症例については更に18種類の糖代謝に関する諸酵素活性を追加測定した。

第 1 例は肝, 筋の生化学な分析結果から Glucose 6 phosphatase 欠損症 (type 1, von Gierhe) と診 断されたが, ガラクトース負荷試験, エピネフリン試験, グルカゴン二重負荷試験の成績は何れも肝内に 正常な構造を有するグリコーゲンの多量沈着が肝の Gluiose 6 phosphatase 欠除に基くものであることを 示した。

第 2 例及び第 3 例の肝と筋の生化学的分析結果の特色は short outer chain を有するグリコーダン量の 增大及び Amylo 1, 6 glucosidase の欠損であり，肝に执いては同時に Glucose 6 phosphatase の減少が あり，とくに第 3 例で著明であった。従ってAmylo 1, 6 glucosidase の欠損 (type 3, Cori) と Glucose 
6 phosphatase の欠損の複数酵素欠損症の疑いがもたれた。しかし G・6・Pase の著明な減少を認めた第 3 例に招いてガラクトース負試験, エピネフリン及びグルカゴンの二重負荷試験の成績は実施した 2 回の 中 1 回で明らかに肝に扔ける G·6・Pase の存在を示した。この事実は糖原病の病型を確実に診断するた めには単に臓器の酵素活性を測定するのみならず，負荷試験を繰返し実施する必要があり，また蔵器の酵 素活性測定も負荷の条件下に和ける測定を併せ実施する必要があることを示している。

第 4 例は発育不良，低血糖があり，各種のホルモン測定により性腺発育不全が証明された例であり，膵 に病変を認めず肝グリコーゲン量の増大を認め糖原病の一種と考えられた。しかしグリコーゲンの構造及 び肝，筋について糖代謝に関する殆んどすべての 22 種に亘る酵素活性を測定したが，グリコーグンの沈着 を説明しうる酵素活性の異常を認め得なかった。

以上の成績から糖原病の病型を診断するに際しては朋及び筋の糖代謝に関する酵素活性を測定するのみ ならず，臨床生化学的に種々の負荷試験を繰返し実施する必要があり，また酵素欠損を証明し得ない糖原 病が存在することを明らかにし得た。

\section{論文審査の結果の要旨}

糖原病の本態は先天的な酵素欠損とされるが, 中には酵素欠損のない例或いは複数の酵素欠損を推定さ せる報告がある。然しこれらは何れも確証に乏しい。著者は肝糖原病の 4 症例を対象として朋の糖原の合 成及び分解酵素 22 種の活性測定，グリコゲン構造の決定と共に糖代謝障害の部位を明確にし得る臨床検查 を繰返すことによりこの問題を検討した。一例に怙いては肝内 Amylo 1, 6-glucosidase の欠損とそれに 伴う外枝の短いグリコゲンの蓄積を示し 糖原病の中 Debranching enzyms の欠損は確実であったが同時 に肝の G-6-Pase も著明に低下し 複数酵素欠損の如き所見を呈した。然し諸種の臨床検査特にグルカゴ ン二重負荷試験は G-6-Pase の存在を示した。この成績は G-6-Pase 活性の低下は欠損ではなくて何ら かの機序による二次的な変化である事を示し, 同時に複数酵素欠損の確診には肝内酵素活性の测定のみで は不備である事を示した。又他の一例では性器発育障害を伴う極希な糖原病例であるが, 解糖系22種の酵 素検索の結果欠損酵素を証明し得ず酵素久損のない糖原病の存在する事を確認した。以上の知見は糖原病 の本態を追究する上に有用な示唆を与えるものである。

よって, 本論文は医学博士の学位論文として価值あるものと認める。 